glycerol-phosphatidylcholine nearly twofold during a 30 -min perfusion. Continuing the perfusions with $10.8 \mathrm{mM}$ glycerol concentration for a 60 -min perfusion resulted in nearly a threefold increase in synthesized glycerol-phosphatidylcholine. This data supports our previous observations that circulating glycerol may be an important precursor for pulmonary phosphatidylcholine synthesis.

\section{REFERENCES AND NOTES}

1. Burton, K.: Study of conditions and mechanism of diphenylamine reaction for colorimetric estimation of deoxyribonucleic acid. Biochem. J., 62: 315 (1956).

2. Godinez, R. I. and Longmore, W. J.: Use of the isolated perfused rat lung in studies on lung lipid metabolism. J. Lipid Res., 14: 138 (1973).

3. Melichar, V., and Wolf, H.: Postnatal changes in the blood serum content of glycerol and FFA in premature infants. Influence of hypothermia and of R. D. S. Biol. Neonate, 11: 50 (1967).

4. Mims, L. C., and Kotas, R. V.: Glycerol as a phosphatidylcholine precursor for the developing mammalian lung. Biol. Neonate, 22 : 436 (1973).

5. Mims, L. C., and Zee, P.: Utilization of glycerol by the developing mammalian lung. Biol. Neonate, $18: 356$ (1971).

6. Naimark, A.: Cellular dynamics and lipid metabolism in the lung. Fed. Proc. 32: 1967 (1973).

7. Scholz, R. W., and Rhoades, R. A.: Lipid metabolism of the rat lung in vitro. Effect of starvation and re-feeding on utilization of $\left[\mathrm{U}-{ }^{14} \mathrm{C}\right]$ glucose by lung slices. Biochem. J., 124: 257 (1971).

8. Wolf, H., Melichar, V., and Michaelis, R.: Elimination of intravenously administered glycerol from the blood of newborns. Biol. Neonatorum 12: 162 (1968).

9. Cottonwood Rabbitry, Coweta, Okla.

10. New England Nuclear Corp., Boston, Mass.

11. Fisher Scientific Co., Fairlawn, N. J.

12. Accepted for publication November 27, 1974.
Coagulant

endotoxin

L-epinephrine leukocytes prostaglandin $\mathrm{E}_{1}$ umbilical cord

\title{
Studies on Tissue Factor Activity and Production by Leukocytes of Human Umbilical Cord and Adult Origin
}

\author{
R. P. A. RIVERS AND W. E. HATHAWAY ${ }^{(47)}$ \\ University of Colorado Medical Center, Denver, Colorado, USA
}

\section{Extract}

Human adult and umbilical cord-derived leukocytes were shown to be capable of generating tissue factor activity on exposure to endotoxin and to reduced $\mathrm{pH}$. Blood for leukocyte separation was collected from normal adults and from newly delivered sections of umbilical cord and mixed leukocyte preparations were obtained by separation over methyl cellulose Hypaque. The coagulant activity of the cell suspension was assayed using a one-stage or two-stage method. Cord-derived leukocytes were shown to develop greater coagulant activity than adult-derived leukocytes when stimulated by endotoxin in vitro at 2,000 cells $/ \mathrm{mm}^{3}$. This response to endotoxin was partially inhibited by prior exposure of the cells to prostaglandin (PG) $\mathrm{E}_{1}$ and to L-epinephrine. Acetylcholine stimulated the production of coagulant activity in the absence of endotoxin. Both cord and adult-derived leukocytes $\left(20,000 / \mathrm{mm}^{3}\right)$ developed coagulant activity when exposed to $\mathrm{pH}$ reduction by lactic or hydrochloric acids and this activity was shown to be tissue factor.

\section{Speculation}

TF production by leukocytes (monocytes) after endotoxin stimulation may explain the frequently encountered association of disseminated intravascular coagulation (DIC) with gram-negative septicemia in the newborn infant. The effect of $\mathrm{pH}$ reduction in association with hypoxia in the perinatal period, by causing tissue factor (TF) activity to become available, may be the trigger mechanism for the coagulation changes of varying degrees of DIC seen in these situations. Necrotizing enterocolitis could be the result of endotoxin penetration of the bowel mucosa which induces monocyte chemotaxis and local TF production by these cells; this would cause local intravascular coagulation with platelet consumption and necrotic sequelae. It remains to be established whether inhibition of in vivo endotoxin-induced monocyte TF production can be achieved with $\mathrm{PGE}_{1}$, and whether such therapy might improve the outcome in gram-negative septicemia.

Evidence of the involvement of leukocytes in blood coagulation has accumulated from several sources; reports have documented the associations between DIC and promyelocytic leukemias $(9,13,27)$, and investigations on the SanarelliShwartzman reaction (SSR) $(10,30,33)$ have shown leukocytes to be essential for the full expression of the reaction.

Evidence more directly linking a mechanism for the initiation of coagulation with leukocytes has come from studies on peritoneally derived rabbit leukocytes (20). These 
cells display little coagulant activity before endotoxin treatment of the animal; after endotoxin administration coagulant activity develops. In vitro studies $(12,15,16)$, in which leukocytes have been incubated with endotoxin, have confirmed that these cells are capable of producing coagulant material identified as TF, and that prior in vitro exposure to puromycin, actinomycin D, or cycloheximide inhibits this response (21).

The newborn infant commonly develops the coagulation abnormalities associated with DIC during gram-negative septicemia (1), after severe birth asphyxia (4), and in association with hyaline membrane disease (2). The mechanisms triggering the activation of coagulation in these situations have not been well defined. One purpose of this study is to consider the procoagulant activity of the leukocyte as a potential triggering mechanism.

The data presented here allow for a comparison to be made between the spontaneous and endotoxin-induced development of coagulant activity during in vitro incubation of adult and umbilical cord-derived leukocytes. The effect of $\mathrm{pH}$ reduction on the TF activity of leukocytes is also described and some additional data on the inhibition of the endotoxin-induced response are presented.

\section{MATERIALS AND METHODS}

Sterile plastic polycarbonated tubes (35), siliconized or unsiliconized glassware, and sterile, endotoxin-free solutions were used throughout all experiments. Limulus polyphemus amoebocyte lysate assay (36) was used to screen reagents for endotoxin contamination (8). Endotoxin lipopolysaccharide B from Escherichia coli 0111:B4 (37) was suspended in buffered saline solutions. Methocel MC (38) and Hypaque (39) were used in the cell separation technique; TC Hanks' salts (37) and Eagle's minimal essential medium with Hanks' salts, with $\mathrm{HaHCO}_{3}$, without serum or glutamine (40), were used for suspending cells in some experiments. Citrate-saline buffer consisted of 1 part $0.1 \mathrm{M}$ sodium citrate and 5 parts isotonic saline.

Rabbit brain thromboplastin (37) was extracted with saline according to the manufacturer's instructions, passed through a cotton plus and stored in aliquots at $-60^{\circ}$. A single preparation was used as the standard for TF activity (nitrogen content, $0.6 \mathrm{~g} \mathrm{~N} / 100 \mathrm{ml}$ ). Inosithin, $50 \mathrm{mg} / 100 \mathrm{ml}$, in Veronal saline buffer $\mathrm{pH} 7.35$, and cephalin prepared from rabbit brain thromboplastin by the method of Bell and Alton (23) were used in the assays of coagulant activity.

Normal human plasma was prepared from blood anticoagulated with $0.1 \mathrm{ml}$ sodium citrate $(3$ parts $0.1 \mathrm{M}$ sodium citrate +2 parts $0.1 \mathrm{M}$ citric acid) and was stored at $-20^{\circ}$ for less than one week before use; human VII-deficient plasma from a congenitally deficient patient was stored at $-60^{\circ}$. Bovine plasma, deficient in factors VII and X, was prepared by the method of Owren and Aas (22). A $\mathrm{BaSO}_{4}$ eluate of celite-exhausted human serum containing factors VII and $\mathrm{X}$ in concentrations equal to those in a pool of 10 normal plasmas was used as a source of these two clotting factors.

Blood for leukocyte separation was collected by a twosyringe technique from normal adults and from newly delivered double-clamped sections of umbilical cord and anticoagulated with 0.1 volume $4 \%$ trisodium citrate. Previous unpublished studies from this laboratory indicate that normal cord citrated plasma obtained thusly has no trace of tissue factor as assayed by the methods outlined below. Blood for preparation of autologous serum was placed in glass tubes at $37^{\circ}$ for $2 \mathrm{hr}$. Mixed leukocyte preparations were obtained by separation over methylcellulose Hypaque (6) followed by centrifugation of upper cell/plasma fraction at $170 \times \mathrm{g}$ for $6 \mathrm{~min}$. The cell button obtained was washed twice with citrate saline buffer at $4^{\circ}$, exposed to water for $30 \mathrm{sec}$ to lyse contaminating erythrocytes, and reconstituted to isotonicity with hypertonic saline. After centrifugation for $4 \mathrm{~min}$ at $140 \times \mathrm{g}$, the cell button was resuspended in Hanks' solution at $4^{\circ}$ while adsorption of serum was performed. The centrifuged serum was mixed with $1 \%$ tricalcium phosphate for two periods of 10 min each at room temperature; the tricalcium phosphate was removed after each period by centrifugation for $10 \mathrm{~min}$ at $2,000 \times g$. Cell counts were performed on suspensions in Hanks' by Coulter counter (41) at concentrations above $2,000 / \mathrm{mm}^{3}$ and in a hemocytometer chamber at counts at or below $2,000 / \mathrm{mm}^{3}$. Differential counts were performed in duplicate on a cytocentrifuged sample stained with Wright's; platelets and erythrocytes were counted by phase microscopy in a hemocytometer chamber.

\section{ASSAY METHODS}

The coagulant activity of the cell suspensions was assayed using a one-stage or two-stage method. In the former, based on the unactivated partial thromboplastin time carried out in plastic tubes at $37^{\circ} 0.05 \mathrm{ml}$ normal platelet-poor plasma with $0.05 \mathrm{ml}$ inosithin added was incubated for $3 \mathrm{~min}$, recalcified with $0.05 \mathrm{ml} \mathrm{CaCl}_{2}, 0.025 \mathrm{M}$, and followed after $15 \mathrm{sec}$ by the addition of $0.05 \mathrm{ml}$ of cell suspension or control material, the clotting time then being recorded. All estimations were carried out in duplicate.

The two-stage method for assaying TF was modified from that of Nemerson (19) as follows.

Stage 1. Barium sulfate eluate $(0.1 \mathrm{ml})$ of Celite-exhausted human serum (source of factors VII-X) $+0.1 \mathrm{ml}$ test mixture (incubate $37^{\circ} 5 \mathrm{~min}$ ). Add $0.05 \mathrm{ml} \mathrm{CaCl}_{2} 0.025 \mathrm{M}$ (incubate $37^{\circ} 1 \mathrm{~min}$ ). Remove $0.1-\mathrm{ml}$ aliquot and add to $0.4 \mathrm{ml}$ trisodium citrate $0.015 \mathrm{M}, 4^{\circ}$.

Stage 2. Cephalin, $0.1 \mathrm{ml}$ ( 1 in 100 in $0.85 \%$ saline $)+0.1 \mathrm{ml}$ factors VII-X-deficient bovine plasma (incubate $37^{\circ}, 45 \mathrm{sec}$ ). Add $0.1 \mathrm{ml} \mathrm{CaCl} 20.025 \mathrm{M}$; wait $15 \mathrm{sec}$ and add $0.1 \mathrm{ml}$ citrated sample from stage 1 , prewarmed to $37^{\circ}$ for $1 \mathrm{~min}$. Record clotting time.

Standard curves were derived for both the one- and two-stage assays from dilutions of rabbit brain thromboplastin. $\mathrm{pH}$ was determined on a $\mathrm{pH} / \mathrm{MV}$ Electrometer, model 245 (42). Lactic acid, L-epinephrine, and acetylcholine were obtained from Sigma Chemical (36), disodium cromoglycate (Intal) was obtained from Fisons (43), and prostaglandin $E_{1}$ was kindly provided by Dr. John Pike (Upjohn) (44). Tests of statistical significance employed the Student paired $t$ test.

\section{RESULTS}

\section{TISSUE FACTOR ACTIVITY OF CORD AND} ADULT-DERIVED LEUKOCYTES

Mixed leukocyte suspensions in adsorbed autologous serum at 20,000 polymorphonuclear neutrophils (PMN) + bands/ $\mathrm{mm}^{3}$ were incubated in the presence and absence of endotoxin $(10 \mu \mathrm{g} / \mathrm{ml})$ and the procoagulant activity was assayed in the one-stage method at hourly intervals for $4 \mathrm{hr}$. Adult and cord-derived samples were incubated in parallel. The mean and SEM percentages of the cell types in the incubation mixtures are given in Table 1. The results are shown in Figure 1. At these cell concentrations, equal amounts of coagulant activity are found following endotoxin stimulation of cord and adult-derived cells; there is no difference in the spontaneous development of slight activity of the non-endotoxin-exposed cells at $4 \mathrm{hr}$.

Since there was no change in the clotting time at $4 \mathrm{hr}$ in cell concentrations from 2,000 to 20,000 per $\mathrm{mm}^{3}$, small differences in coagulant activity between adult and cord samples could readily be concealed at the high cell concentrations used in the incubations recorded above. Five incubations of adult and cord-derived leukocytes at a total cell concentration of $2,000 / \mathrm{mm}^{3}$ with endotoxin stimulation were therefore performed. It may be seen (Table 2) that the mean clotting 
Table 1. Leukocyte differential counts on separated adult-and cord-derived blood incubated at $20,000 / \mathrm{mm}^{3}$ of polymorphonuclear neutrophils (PMN) and bands ${ }^{1}$

\begin{tabular}{lrrrrr}
\hline & PMN & Bands & Lymphocytes & Monocytes & Eosinophils \\
\hline Adult (10 samples) & $69.8 \pm 2.9$ & $14.4 \pm 2.0$ & $8.1 \pm 3.1$ & $5.0 \pm 0.7$ & $4.0 \pm 0.9$ \\
Cord (10 samples) & $64.9 \pm 2.4$ & $31.0 \pm 1.6$ & $10.3 \pm 3.2$ & $8.4 \pm 1.2$ & $3.3 \pm 0.8$ \\
& & & & $P<0.025$ \\
\hline
\end{tabular}

'Values expressed as mean percentage \pm SEM. Platelet contamination $\leqslant 4 / 100$ leukocytes. Ery throcyte contamination $\leqslant 5 / 100$ leukocy tes.

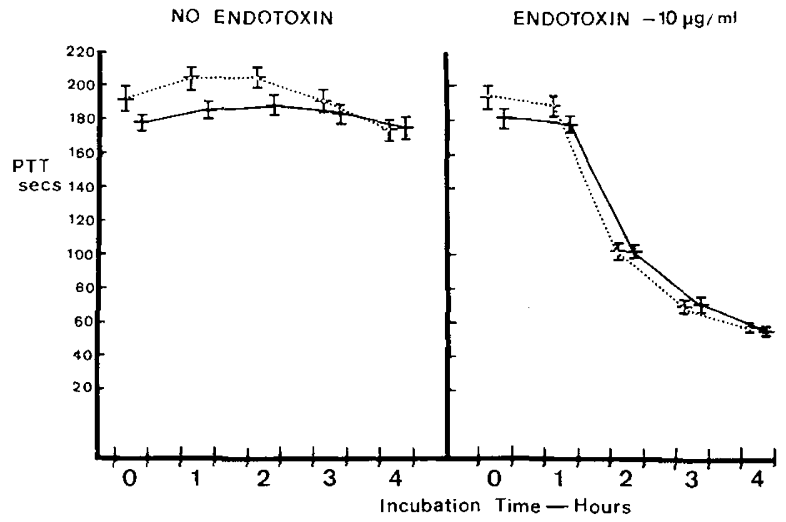

Fig. 1. Coagulant activity developed by adult and cord-derived leukocyte suspensions: spontaneous and endotoxin induced. Leukocytes $\left(20,000 / \mathrm{mm}^{3}\right.$ polymorphonuclear neutrophils + bands) suspended in autologous adsorbed serum were incubated at $37^{\circ}$ in the presence and absence of endotoxin, $10 \mu \mathrm{g} / \mathrm{ml}$. Coagulant activity was assayed by the one stage method at hourly intervals. Mean values + SEM from 10 adult (- - ) and 10 cord-derived (- $)$ samples. PTT: partial thromboplastin time.

Table 2. Means and SEM of clotting times (one-stage assay) of adult-and cord-derived mixed leukocyte populations $4 \mathrm{hr}$ after endotoxin exposure $(10 \mu \mathrm{g} / \mathrm{ml})$ at $37^{\circ}, 2,000$ cells $/ \mathrm{mm}^{3}$

\begin{tabular}{lcc}
\hline & $\begin{array}{c}\text { Clotting time, sec } \\
\text { (mean) }\end{array}$ & SEM \\
\hline Adult (5 samples) & 61.1 & 2.9 \\
Cord (5 samples) & 53.1 & 1.4 \\
& $P<0.05$ & \\
\hline
\end{tabular}

time at $4 \mathrm{hr}$ given by cord-derived leukocytes is shorter than that given by adult-derived cells, the difference being significant at $P<0.05$.

\section{EFFECT OF PH ON LEUKOCYTE COAGULANT ACTIVITY}

The effect of lowering the $\mathrm{pH}$ with lactic acid on the coagulant activity of mixed leukocyte suspensions of cord origin containing $20,000 / \mathrm{mm}^{3}$ PMN neutrophils + bands is seen in Figure 2. Coagulant activity develops by 7 min with $\mathrm{pH}$ reduction to 6.6 and below. This activity was identified as TF by assay in the specific two-stage method, and by the failure of the cell suspension to shorten the clotting time of factor VII-deficient plasma in the one-stage assay. Progressive loss of activity is seen after $15 \mathrm{~min}$ incubation at $37^{\circ}$.

Further experiments were carried out on adult-derived leukocytes which develop an equivalent amount of coagulant activity for a given $\mathrm{pH}$ reduction. In order to determine whether the lactic acid concentration or $\mathrm{pH}$ reduction of itself was responsible for the observed development of coagulant activity, the lactic acid was buffered by prior addition of sodium bicarbonate. At a lactic acid concentration of 120

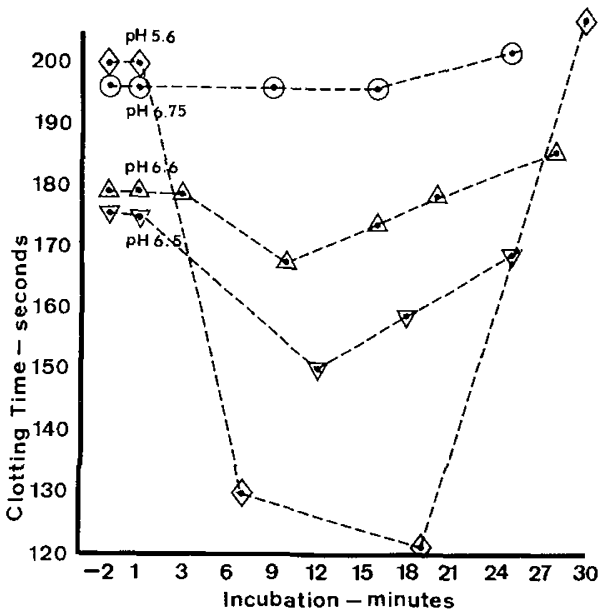

Fig. 2. Coagulant activity of cord-derived leukocytes $\left(20,000 / \mathrm{mm}^{3}\right)$ after reduction in $\mathrm{pH}$ with lactic acid. The coagulant activity (one-stage method) was measured before and after addition of lactic acid to achieve $\mathrm{pH}$ reductions of increasing magnitude.

$\mathrm{mg} / 100 \mathrm{ml}$ in the buffered cell suspension, no coagulant activity was found, whereas at a concentration of $100 \mathrm{mg} / 100$ $\mathrm{ml}$, producing a $\mathrm{pH}$ of 6.37 in the nonbuffered suspension, development of coagulant activity occurred. To confirm this $\mathrm{pH}$ effect, dilute hydrochloric acid was substituted for lactic acid and at a cell concentration of $40,000 / \mathrm{mm}^{3}$ of PMN neutrophils + bands, the coagulant activity was assayed in the two-stage specific assay. A higher cell concentration than used for the detection of activity by the one-stage assay was required because of the different sensitivities of the two assay methods. For a similar $\mathrm{pH}$ reduction $(\mathrm{pH}=6.5)$, hydrochloric and lactic acids caused similar amounts of TF activity to develop. Further experimentation indicated that repeat exposure to lactic acid after spontaneous partial $\mathrm{pH}$ correction after initial exposure did not result in further development of coagulant activity. However, the cells were shown to be responsive to endotoxin after the initial development of coagulant activity induced by low $\mathrm{pH}$ exposure.

\section{COMPARISON OF ONE- AND TWO-STAGE ASSAYS \\ OF ENDOTOXIN-INDUCED COAGULANT ACTIVITY}

Experiments were performed to investigate the difference in coagulant activity as measured by the one- and two-stage methods when this activity was expressed in micrograms of $\mathrm{N}_{2}$ tissue factor per milliliter of cells. After centrifugation at 250 $X g$ for $10 \mathrm{~min}$ to remove the cells, little change in TF activity as measured in the two-stage assay was found $(0.5-1.2 \mu \mathrm{g} / \mathrm{ml})$ but the activity $(3.5-7.9 \mu \mathrm{g} / \mathrm{ml})$ measured by the one-stage method had diminished to a level closely similar to that found in the specific assay.

INVESTIGATION OF INHIBITORY AND STIMULANT ACTIVITY OF COMPOUNDS ON TF PRODUCTION BY LEUKOCYTES

Adult-derived leukocytes were incubated with L-epinephrine, $\mathrm{PGE}_{1}$, or disodium cromoglycate (Intal) before endo- 
toxin exposure at concentrations shown in Figure 3. None of these substances induced the development of TF activity in the cell suspensions when incubated in the absence of endotoxin. However, inhibition of the development of endotoxin-induced TF activity by these cell suspensions after prior exposure of the cells to L-epinephrine and to $\mathrm{PGE}_{1}$ was found. Neither disodium cromoglycate nor acetylcholine had any inhibitory effect on the development of this endotoxininduced TF activity, but acetycholine, in the absence of detectable endotoxin, was shown to have a small stimulatory effect.

\section{DISCUSSION}

The investigations of the role of leukocytes in coagulation in recent years have followed the initial demonstrations of changes in the levels of coagulation factors I, VII, VIII, and XII after endotoxin administration to rabbits, described in studies on the SSR, in which two spaced doses of endotoxin result in the development of bilateral renal glomerular capillary thrombi and DIC $(10,17,30,33)$. The SSR can be prevented, as can the changes in coagulation factor levels, by rendering the animals neutropenic by nitrogen mustard before endotoxin challenge. This protective effect is lost if a portion of marrow is isolated from the nitrogen mustard. Prevention of the development of the SSR can also be achieved by prior anticoagulation of the animal (11).

Tissue factor production after endotoxin stimulation of mixed ieukocyte suspensions in vitro has been attributed to PMN neutrophils and lymphocytes (32), and, after in vivo

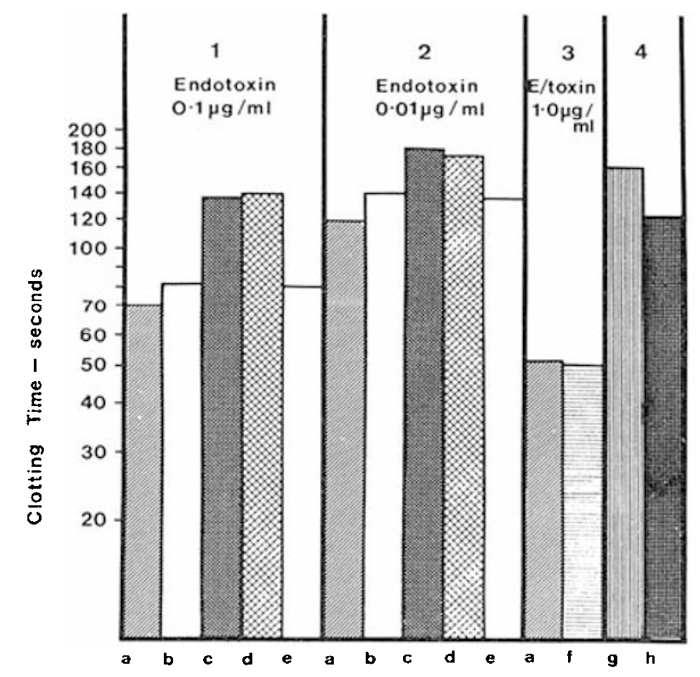

Fig. 3. Effect of L-epinephrine, prostaglandin $E_{1}$, (PGE), ethyl alcohol, disodium cromoglycate, and acetylcholine on coagulant activity of mixed leukocyte suspensions $\left(2,000 / \mathrm{mm}^{3}\right.$ total $)$ in minimal essential medium-Hanks' salts assayed at $4 \mathrm{hr}$ in the one-stage method. $a$ : cells + endotoxin $(E /$ toxin $) ; b$ : cells + Lepinephrine $\left(1.5 \times 10^{-5} \mathrm{M}\right)$ incubated $15 \mathrm{~min}$ at $37^{\circ}$ before endotoxin stimulation; $c$ : cells $+\mathrm{PGE}_{2}$ $(5 \mu \mathrm{g} / \mathrm{ml})$, procedure as in $b ; d$ : cells $+\mathrm{PGE}_{1}(3 \mu \mathrm{g} / \mathrm{ml})$, procedure as in $b$; $e$ : cells + ethyl alcohol $(0.6 \%)$ (solvent for $\mathrm{PGE}_{1}$ ), procedure as in $b$; $f$ : cells + disodium cromoglycate (Intal) $\left(1 \times 10^{3} \mu \mathrm{g} / \mathrm{ml}\right)$, procedure as in $b$; $g$ : cells unstimulated in minimal essential medium-Hanks' salts; $h$ : cells + acetylcholine $\left(10^{-10} \mathrm{M}\right)$. At the concentrations tested, L-epinephrine and PGE, both inhibit the development of coagulant activity induced by subsequent endotoxin stimulation; ethyl alcohol has a slight inhibitory effect. Disodium cromoglycate has no inhibitory effect, and was tested at $0.01,0.1,1.0$, and $1 \times 10^{3} \mu \mathrm{g} / \mathrm{ml}$. None of the above substances stimulated TF production when incubated with the cell suspensions in the absence of endotoxin. Cells treated with acetylcholine from $10^{-6}-10^{-10} \mathrm{M}$ produced coagulant activity as indicated by a shortening of the clotting time of the one stage assay when compared with untreated cells. endotoxin stimulation, to rabbit peritoneally derived macrophages (20), although the coagulant activity has most frequently been studied using high cell concentrations $\left(\geqslant 10,000 / \mathrm{mm}^{3}\right)$ and in the presence of inevitable monocyte contamination. Additional experiments performed in this laboratory and to be reported elsewhere indicate that the monocyte is the peripheral blood cell capable of production and release of TF when stimulated by endotoxin. Indeed this finding would account for the greater TF activity of mixed leukocyte cell suspensions of cord origin compared with adult-derived cell suspensions when incubated at $2,000 / \mathrm{mm}^{3}$ total count, since the monocyte levels were higher in the cord-derived suspensions (Table 3). Platelets, which contaminated cell suspensions to a small extent, have not been shown to produce TF on endotoxin stimulation (17).

The results reported here establish that cord-derived leukocytes are capable of generating TF activity on exposure to endotoxin and to reduced $\mathrm{pH}$. The occurrence of DIC in newborn infants in association with gram-negative septicemia may be explicable in terms of TF release by stimulated leukocytes (monocytes). Whether a reduction in $\mathrm{pH}$ can activate coagulation via the TF pathway in vivo remains to be established. Severe $\mathrm{pH}$ reduction is likely to occur in the microcirculation in association with the hypoxia and reduced cardiac output encountered during severe birth asphyxia, hyaline membrane disease, and severe apnea of prematurity, where systemic arterial $\mathrm{pH}$ values of below 7.0 and lactic acid levels of above $50 \mathrm{mg} / 100 \mathrm{ml}$ have been encountered $(3,26)$. Since TF has been immunologically identified in plasma membranes of many cell types including vascular endothelium (34), and changes in the characteristics of cell membranes are known to occur on $\mathrm{pH}$ reduction (29), preformed TF at the cell surface may become available for interaction with factor VII in these situations, although the experiments described here have only shown the TF of leukocytes to become available on $\mathrm{pH}$ reduction.

The explanation of the difference in clotting activity, expressed as micrograms of $\mathrm{N}_{2} \mathrm{TF}$ per milliliter of cells, of endotoxin-exposed cells as measured by the one- and two-stage methods is not immediately apparent. Optimal amounts of phospholipid are provided by the inosithin in the one-stage assay and increasing its concentration to $100 \mathrm{mg} / 100 \mathrm{ml} \mathrm{did}$ not reduce the clotting time of the plasma, so that an additional source of phospholipid from the cells should not further reduce the clotting time. Some other attribute of the cells must be implicated since the TF activity assayed by the two-stage method differs little in pre- and postcentrifugation samples of the same origin. Parallel observations have been made in studies on platelet factor 3 where even washing of the platelets increases this activity as compared with "intact" platelets, and it has been suggested that the platelet factor 3 is made "available" on the platelet surface by such treatment (18).

Stimuli, including endotoxin, which cause increased adenylate cyclase and cyclic adenosine $3^{\prime}, 5^{\prime}$-monophosphate levels in leukocytes have been implicated in some leukocyte metabolic responses $(5,7,25,31)$, and the studies performed here were designed to determine whether TF activity might be

Table 3. Leukocyte differential counts on adult-and cordderived separated blood incubated at $2,000 / \mathrm{mm}^{3}$ total count ${ }^{1}$

\begin{tabular}{|c|c|c|c|c|c|}
\hline & $\mathrm{PMN}^{2}$ & Bands & $\begin{array}{l}\text { Lympho- } \\
\text { cytes }\end{array}$ & $\begin{array}{l}\text { Mono- } \\
\text { cytes }\end{array}$ & $\begin{array}{c}\text { Eosino- } \\
\text { phils }\end{array}$ \\
\hline Adult & $69.4 \pm 2.6$ & $7.4 \pm 1.0$ & $11.0 \pm 1.7$ & $4.4 \pm 0.9$ & $4.2 \pm 1.7$ \\
\hline Cord & $66 \pm 1.8$ & $9.2 \pm 1.0$ & $11.0 \pm 1.7$ & $\begin{array}{l}9.2 \pm 1.0 \\
P<0.025\end{array}$ & $4.6 \pm 0.8$ \\
\hline
\end{tabular}

${ }^{1}$ Values are expressed as mean percentage \pm SEM.

${ }^{2}$ Polymorphonuclear neutrophils. 
generated after cell exposure to such stimuli, or whether endotoxin-induced TF activity might be reduced by prior cell exposure to these compounds. Disodium cromoglycate was also tested since it has been shown to stabilize lysosomal membranes and to protect animals from endotoxin induced shock and death (28); prior treatment of animals with $\mathrm{PGE}_{1}$ has also been shown to have a similar protective effect (24). The data presented here show that TF production was markedly inhibited by prior exposure of the cells to $\mathrm{PGE}_{1}$ and to some extent by L-epinephrine; no TF was generated on stimulation of the cells with these agents in the absence of endotoxin. Acetylcholine, which causes a rise in cyclic guanosine monophosphate level in lymphocytes associated with an increase in protein synthesis (14), was shown to induce some TF generation by mixed leukocyte suspensions in the absence of endotoxin.

\section{SUMMARY}

Human umbilical cord-derived leukocytes were shown to develop greater coagulant activity than adult-derived leukocytes when stimulated by endotoxin at 2,000 celis $/ \mathrm{mm}^{3}$. This difference is explained by the higher monocyte levels in the cord derived cell suspensions and was not perceived at high cell concentrations $\left(20,000 / \mathrm{mm}^{3}\right)$ because of the relationship between the clotting time of the one stage assay and the number of cells stimulated. Both cord- and adult-derived leukocytes $\left(20,000 / \mathrm{mm}^{3}\right)$ developed coagulant activity when exposed to $\mathrm{pH}$ reduction by lactic or hydrochloric acid and this activity was shown to be tissue factor. Partial inhibition of endotoxin-induced coagulant activity was found after prior incubation of the cells with $\mathrm{PGE}_{1}$ and L-epinephrine; acetylcholine stimulated the production of coagulant activity in the absence of endotoxin, and had no inhibitory effect on endotoxin-induced TF production.

\section{REFERENCES AND NOTES}

1. Alebouyeh, M., Remien, A., and Marget, W.: Incidence of disseminated intravascular coagulation in the course of septicemia in newborn infants. Z. Kinderheilk., 109: 326 (1971).

2. Alstatt, L. B., Dennis, L. H., Sundell, H., Malan, A., Harrison, V., Hedvall, G., Eichelberger, J., Fogel, B., and Stahlman, M.: Disseminated intravascular coagulation and hyaline membrane disease. Biol. Neonate, 19: 227 (1971).

3. Beca, J. P., and Scopes, J. W.: Serial determinations of blood lactate in respiratory distress syndrome. Arch. Dis. Childhood, 47: $550(1972)$.

4. Bley1, U., and Bein, G.: Zur Pathogenese und Differentialdiagnose der Thrombose beim Neugeborenen. Z. Kinderheilk., 109: 83 (1970).

5. Bourne, H. R., Lehrer, R. I., Lichtenstein, L. M., Weissman, G. and Zurier, R.: Effects of cholera enterotoxin on adenosine $3^{\prime}, 5^{\prime}$-monophosphate and neutrophil function. Comparison with other compounds which stimulate leucocyte adenyl cyclase. J. Clin. Invest., 52: 698 (1973).

6. Boyum, A.: Separation of leukocytes from blood and bone marrow. Scand. J. Clin. Lab. Invest. Suppl. 97, 21 (1968).

7. Cline, M. J., Melmon, K. L., Davis, W. C., and Williams, H. E.: Mechanism of endotoxin interaction with human leukocytes. Brit. J. Haematol., 15: 539 (1968).

8. Cooper, J. F., Levin, J., and Wagner, H. N.: Quantitative comparison of in vitro and in vivo methods for the detection of endotoxin. J. Lab. Clin. Med., 78: 138 (1971).

9. Didisheim, P., Trombold, J. S., Vandervoort, R. L. E., and Misbashan, R. S.: Acute promyelocytic leukemia with fibrinogen and factor $\mathrm{V}$ deficiencies. Blood, 23: 717 (1964).

10. Forman, E. N., Abildgaard, C. F., Bolger, J. F., Johnson, C. A., and Schulman, I.: Generalized Shwartzman reaction: Role of the granulocyte in intravascular coagulation and renal cortical necrosis. Brit. J. Haematol., 16: 507 (1969).

11. Good, R. A., and Thomas, L.: Studies on the generalized Shwartzman reaction. IV. Prevention of the local and general Shwartzman reaction with heparin. J. Exp. Med., 97: 871 (1953).
12. Gralnick, H. R., and Abrell, E.: Studies of the procoagulant fibrinolytic activity of promyelocytes in acute promyelocytic leukaemia. Brit. J. Haematol., 24: 89 (1973).

13. Gralnick, H. R., Bagley, J., and Abrell, E.: Heparin treatment for the hemorrhagic diathesis of acute promyelocytic leukemia. Amer. J. Med., 52: 167 (1972).

14. Hadden, J. W., Hadden, E. M., Meetz, G., Good, R. A., Haddox, M. K., and Goldberg, N. D.: Cyclic GMP in cholinergic and mitogenic modulation of lymphocy te metabolism and proliferation. Fed. Proc. 32: 1022/4531 (1973).

15. Kociba, G. J., Loeb, W. F., and Wall, R. L.: Development of procoagulant (tissue thromboplastin) activity in cultured leucocytes. J. Lab. Clin. Med., 79: 778 (1972).

16. Lerner, R. G., Goldstein, R., and Cummins, G.: Stimulation of human leukocyte thromboplastin activity by endotoxin. Proc. Soc. Exp. Biol. Med., 138: 145 (1971).

17. Lerner, R. G., Rapaport, S. I., and Spitzer, J. M.: Endotoxininduced intravascular clotting: The need for granulocytes. Thromb. Diath. Haemorrh. 20: 430 (1968).

18. Marcus, A. J., and Zucker, M. B.: The Physiology of Blood Platelets, p. 17 (Grune \& Stratton, Inc., New York, 1965).

19. Nemerson, Y.: The phospholipid requirement of tissue factor in blood coagulation. J. Clin. Invest., 47: 72 (1968).

20. Niemetz, J.: Coagulant activity of leukocytes: Tissue factor activity. J. Clin. Invest., 51: 307 (1972).

21. Niemetz, J.: The role of protein synthesis on the generation of tissue factor activity by leukocytes. Proc. Soc. Exp. Biol. Med., 139: 1276 (1972)

22. Owren, P. A., and Aas, K.: The control of dicumarol therapy and the quantitative determination of prothrombin and proconvertin. Scand. J. Clin. Lab. Invest., 3: 201 (1951).

23. Procter, R., and Rapaport, S.: The partial thromboplastin time with kaolin. Amer. J. Clin. Pathol., 36: 212 (1961).

24. Raflo, G. T., Wangensteen, S. L., Glenn, T. M., and Lefer, A. M.: Mechanism of the protective effects of prostaglandins $E_{1}$ and $F_{2}$ $\alpha$ in canine endotoxin shock. Europ. J. Pharmacol., 24: 86 (1973).

25. Remold-O'Donnell, E.: Stimulation and desensitization of macrophage adenylate cyclase by prostaglandins and catecholamines. J. Biol. Chem., 249: 3615 (1974).

26. Rosenfeld, W. N., Fox, H. A., and Sarkozi, L.: Lactic acidemia in sick neonates. Pediat. Res., 8: 450/176 (1974).

27. Rosenthal, R. L.: Acute promyelocytic leukemia associated with hy pofibrinogenemia. Blood, 21: 495 (1963).

28. Schumer, W., and Erve, P. R.: Antiendotoxin effect of disodium cromoglycate. Toxicon, 11: 509 (1973).

29. Shipley, G. G.: In: D. Chapman and D. F. H. Wallach: Biological Membranes, p. 46 (Academic Press, New York 1973).

30. Stetson, C. A., and Good, R. A.: Studies on the mechanism of the Shwartzman phenomenon: Evidence for the participation of polymorphonuclear leukocytes in the phenomenon. J. Exp. Med., 93: 49 (1951).

31. Stole, $V_{.}:$Restrained adenyl cyclase in human neutrophils: Stimulation of cyclic adenosine $3^{\prime}: 5^{\prime}$-monophosphate formation and adenyl cyclase activity by phagocy tosis and prostaglandins. Blood, 43: 743 (1974).

32. Sudershan, K. G., and Niemetz, J.: Tissue factor activity of normal and leukemic cells. Blood, 42: 729 (1973).

33. Thomas, L., and Good, R. A.: Studies on the generalized Shwartzman reaction. 1. General observations concerning the phenomenon. J. Exp. Med., 96: 605 (1952).

34. Zeldis, S. M., Nemerson, Y., Pitlick, F. A., and Lentz, T. L.: Tissue factor (thromboplastin): Localization to plasma membranes by peroxidase conjugated antibodies. Science, 175: 766 (1972).

35. Falcon Plastics, Oxnard, Calif.

36. Sigma Chemical Co., St. Louis, Mo.

37. Difco Labs, Detroit, Mich.

38. Dow Chemical Co., Midland, Mich.

39. Winthrop Laboratories, N. Y.

40. Flow Laboratories, Inc., Rockville, Md

41. Coulter Electronics Inc., Hialeah, Fla.

42. Instrumentation Laboratory, Inc., Watertown, Mass.

43. Fisons Corp., Bedford, Mass.

44. Upjohn Co., Kalamazoo, Mich

45. The authors wish to thank Dr. J. R. Humbert for information concerning cell separation methods, and Dr. J. A. Goldstein for expert technical assistance in screening for endotoxin.

46. Dr. R. P. A. Rivers was in tenure of a Medical Research Council (UK) travelling fellowship during the course of these investigations.

47. Requests for reprints should be addressed to: W. E. Hathaway, M.D., University of Colorado Medical Center, 4200 E. Ninth Ave., Denver, Colo. 80220 (USA).

48. Accepted for publication December 3, 1974. 